\title{
Integration of Distributed Energy Resources into Offshore and Subsea Grids
}

\author{
Razieh Nejati Fard and Elisabetta Tedeschi
}

\begin{abstract}
The main goal of this paper is to outline characteristics and critical aspects related to the design and operation of offshore and subsea electric distribution grids, particularly in the case of high penetration of distributed and intermittent renewable energy sources. At first, the paper provides an overview of electric loads operating in the ocean environment, surveys their power and energy demands and presents their main operational characteristics and corresponding maturity of technology. Subsequently, the potential of marine renewable energy sources is identified by analyzing their degree of development, typical power range and suitability to supply the offshore loads. Based on an up-to-date review of previous studies and real test cases, this paper shows how conditions to enable the development of "offshore smart grids" can be met and it outlines emerging trends in the electrification of the ocean space.
\end{abstract}

Index Terms - Deep-sea mining, marine energy, offshore grids, offshore wind, oil and gas platforms, subsea applications.

\section{INTRODUCTION}

$\mathrm{D}^{1}$ IFFERENT types of renewable energy sources, mostly intermittent in nature, are present in the marine environment, spread over vast regions. Since oceans also host several load centers, characterized by power consumptions of dozens of MW and often located in remote areas, matching power demand and local generation through offshore electric grids could bring advantages in terms of efficiency, grid stability, sustainability and costs, compared to present supply solutions. This, however, requires the proper integration and coordination of various distributed energy systems.

The "energization" of the ocean space will occur, at first, through the deployment of independent offshore/subsea microgrids. The variable nature of both offshore loads and marine resources can generate bi-directional power flows, representing challenges for control and protection coordination that are non-dissimilar to those of onshore smart grids. Moreover, the prevailing operation as isolated electric systems will require the careful assessment of stability limits and power quality issues, whereas the possibility of a subsequent interconnection to other offshore systems or integration into the onshore power system, will require the elaboration of control strategies supporting the

Manuscript received February15, 2018. This work was supported by NTNU Oceans Pilot Program on Deep-sea Mining.

The authors are with the Department of Electric Power Engineering, Norwegian University of Science and Technology (NTNU), O.S. Bragstads plass 2E, E-block 3rd floor, 7034 Trondheim, Norway (e-mails: razieh. nejati@ntnu.no; Elisabetta.tedeschi@ntnu.no).

Digital Object Identifier 10.24295/CPSSTPEA.2018.00004 grid-connected mode of operation. The first necessary step towards the development of any offshore smart grids is, however, to gain an accurate understanding of the power and/or energy characteristics of resources and loads.

Although "moving offshore" has been clearly identified as one of the emerging challenges within the implementation of the smart grid paradigm [1], tailored analyses highlighting the criticalities of offshore grid deployments, compared to corresponding onshore applications, are scarce. In particular, available literature and previous state-of-the-art reviews tend to focus only separately on the different components of offshore and subsea distributed energy systems. Several contributions have surveyed offshore wind developments [2], [3] including floating solutions [4] or generation from other marine energy sources [5]-[7]. Other references have focused on specific offshore loads, mostly highlighting structural and construction aspects [8], [9] or surveyed offshore energy storage applications [10]-[12]. However, cross-cutting contributions are still very limited [13] and a systematic study relating the offshore power generation capabilities with the electrical loads requirements and energy storage potential in the perspective of distributed energy systems is currently missing. The goal of this paper is to contribute to filling this gap, by showing how different offshore components can complement each other and contribute to grid services provision and efficient system operation. The analysis is based on previous techno-scientific contributions, but includes also some of the newest emerging offshore technologies, such as deep-sea mining, which, due to pits novelty, has found limited space in previous papers [14].

\section{Electric Loads In the Offshore and Subsea ENVIRONMENT}

Electric loads in the ocean environment (e.g. Fig. 1) are similar to concentrated industrial onshore loads. However, the space limitation, cost of maintenance and usually distance to the utility grid differentiate them from the onshore counterparts. The offshore loads can be classified based on power consumption, distance from shore, operational requirements, load cycles, and depth of operation. A significant set of representative ocean loads have been surveyed, which are classified into four main types and presented in this section based on their main application domain. Some of their characteristics are captured in Fig. 2 and Fig. 3.

\section{A. Oil and Gas Platforms}

The majority of offshore loads are represented by power consumptions associated to the Oil and Gas (O\&G) industry (Fig. 1). 


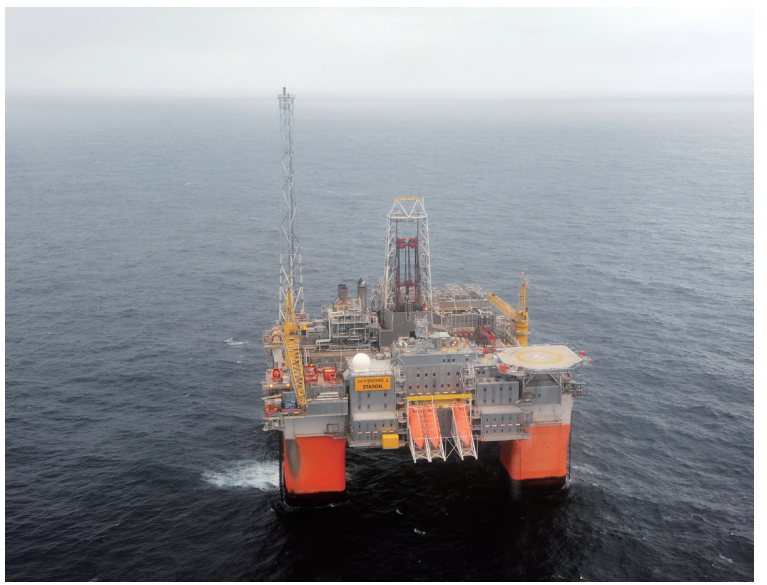

Fig. 1. Snorre B O\&G platform in the Norwegian North Sea (photo: courtesy of Statoil).

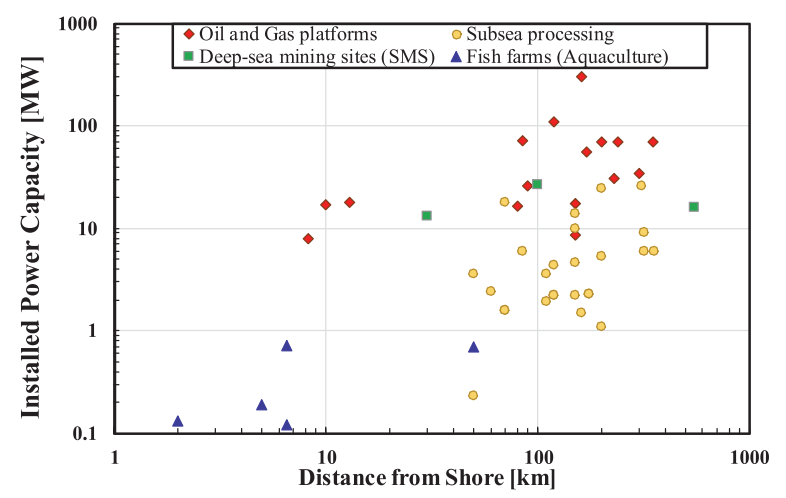

Fig. 2. Installed power capacity and distance from shore of surveyed ocean loads [15]-[61].

Globally, more than 1300 O\&G rigs are located offshore [62], the largest share of which are in the North Sea (185) and Gulf of Mexico (175). Although drilling an offshore well is similar to the onshore drilling process, offshore rigs face additional challenges due to the water depth (up to $3 \mathrm{~km}$, and increasing, for ultradeep water applications) and the need for an anchored, stable, surface structure to host the drilling equipment and additional facilities. Moreover, compared to onshore wells, offshore O\&G platforms need special equipment for oil processing and transportation after extraction. Although this significantly increases the costs $(+1500 \%)$, the daily production of offshore O\&G can be one order of magnitude higher than that of onshore wells and last typically for 10-20 years [63]. Typical power consumptions of offshore O\&G platforms are in the range 5-300 MW [64], mostly supplied by local gas turbines [65] or diesel generators [66], [67]. Such power generation strategies cause significant greenhouse gas emissions, triggering increasing interest for more sustainable solutions. The electric distribution system of O\&G platforms is characterized as a weak electric grid: power quality issues, such as high reactive power demand/low power factor [68], voltage and current harmonics, voltage notches and common mode voltages [69] may increase the losses and compromise the lifetime and operating conditions of electric components. The estimated financial loss for incidents due to poor

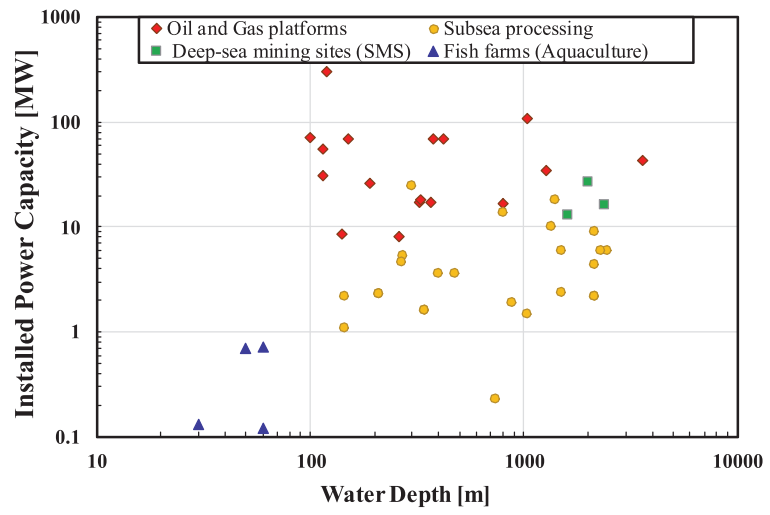

Fig. 3. Installed power capacity and water depth of operation of surveyed ocean loads [15]-[61].

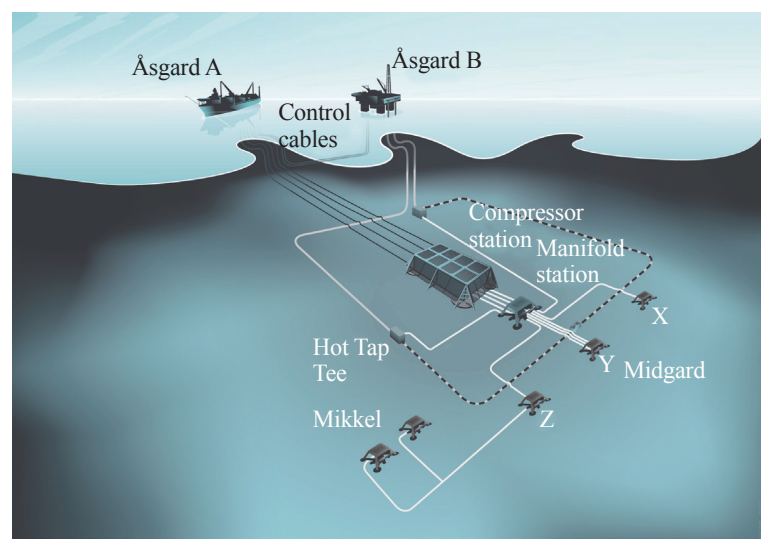

Fig. 4. Asgård gas compression station located in the Norwegian Sea at $300 \mathrm{~m}$ water depth with 24.4 MW power consumption (image: courtesy of Statoil).

power quality in the $O \& G$ sector is $250,000-750,000$ euros per day [68]. In order to increase the energy efficiency and reduce the $\mathrm{CO}_{2}$ and $\mathrm{NO}_{\mathrm{x}}$ emissions, several platforms have been recently electrified, using either High-Voltage Alternating Current (HVAC) [70], [71] or High-Voltage Direct Current (HVDC) [72], depending on their power demand and distance from shore [73]. Among the advantages of "power-from-shore" solutions, in addition to high efficiency, there are high availability $(\sim 99 \%)$ and systems lifetime ( $\sim 30$ years), as well as reduced maintenance needs and repair time [74].

\section{B. Subsea Processing Plants}

With recent discoveries in remote and ultradeep waters and harsh environments, such as the Arctic Ocean, an additional trend in the $O \& G$ industry is to remove as many components and processing systems as possible from the floating production units and install them on the seabed (e.g. Fig. 4), reducing the required space on the platform or even removing the platform [74], [75]. Subsea processes include gas compression, boosting, water injection and separation. The main power consumptions and deployment characteristics of most of the subsea processing plants currently in operation are presented in TABLE I. Additional details can be found in [76]. Due to the extreme operating conditions, multi-MW power demands, step-out distances up to 
TABLE I

Characteristics of the Main Operational Subsea Processing Plants as of February 2017 (adapted from [76])

\begin{tabular}{|c|c|c|c|c|c|c|}
\hline & Name of the field or project & Basin/Country & $\begin{array}{l}\text { Subsea power } \\
{[\mathrm{kW}]}\end{array}$ & $\begin{array}{l}\text { Water depth } \\
{[\mathrm{m}]}\end{array}$ & $\begin{array}{l}\text { Distance from } \\
\text { shore }[\mathrm{km}]\end{array}$ & $\begin{array}{l}\text { Tie-back dis- } \\
\text { tance }[\mathrm{km}]\end{array}$ \\
\hline $\begin{array}{l}\text { Gas } \\
\text { compression }\end{array}$ & $\begin{array}{l}\text { Asgård, Midgård and Mikel } \\
\text { fields (Fig. 4) }\end{array}$ & Offshore Norway & 24,400 & 300 & 200 & 40 \\
\hline \multirow{4}{*}{$\begin{array}{l}\text { Water } \\
\text { injection }\end{array}$} & Troll C pilot & Offshore Norway & 1,600 & 340 & 70 & 3.5 \\
\hline & Tordis & Offshore Norway & 2,300 & 210 & 175 & 11 \\
\hline & Tyrihans & Offshore Norway & 5,400 & 270 & 200 & 31 \\
\hline & Albacora-l'este field & Campos basin (BR) & 3,600 & 400 & 110 & 9 \\
\hline \multirow{6}{*}{ Separation } & Troll C pilot & Offshore Norway & 1,600 & 340 & 70 & 3.5 \\
\hline & Tordis & Offshore Norway & 2,300 & 210 & 175 & 11 \\
\hline & Parque Das Conchas & Campos basin (BR) & 4,400 & 2,150 & 120 & 25 \\
\hline & Perdido & USA (Gulf of Mexico) & 6,000 & 2,438 & 354 & 0 \\
\hline & Pazflor & Angola & 13,800 & 800 & 150 & 4 \\
\hline & Marlim & Campos basin (BR) & 1,900 & 878 & 110 & 3.8 \\
\hline \multirow{14}{*}{ Boosting } & Mutineer & NW Shelf Australia & 2,200 & 145 & 150 & 7 \\
\hline & Brenda\&Nicol fields & UK North Sea & 1,100 & 145 & 200 & 8.5 \\
\hline & Vincent & NW Shelf Australia & 3,600 & 475 & 50 & 3 \\
\hline & Golfinho Field & Espirito Santo Basin (BR) & 2,400 & 1,500 & 60 & 11 \\
\hline & Parque Das Conchas (ph1) & Campos basin (BR) & 2,200 & 2,150 & 120 & 9 \\
\hline & Parque Das Conchas (ph2) & Campos basin (BR) & 2,200 & 2,150 & 120 & 9 \\
\hline & Jubarte field & Espirito Santo Basin (BR) & 18,000 & 1,400 & 70 & 8 \\
\hline & Barracuda & Campos basin (BR) & 1,500 & 1,040 & 160 & 10.5 \\
\hline & Montanazo \& Lubina & Mediterranean & 230 & 740 & 50 & 12.3 \\
\hline & Jack \& St Malo & USA (Gulf of Mexico) & 9,000 & 2,134 & 320 & 13 \\
\hline & Rosa/Girasol & Angola & 10,000 & 1,350 & 150 & 18 \\
\hline & Draugen & Offshore Norway & 4,600 & 268 & 150 & 4 \\
\hline & Julia & USA (Gulf of Mexico) & 6,000 & 2,287 & 320 & 27.2 \\
\hline & Parque das baleias & Espirito Santo Basin (BR) & 6,000 & 1,500 & 85 & 10 \\
\hline
\end{tabular}

tens of $\mathrm{km}$, and operating water depths up to $3 \mathrm{~km}$, the technology for subsea processing is continuously evolving. The entire power distribution system, either AC or DC, including umbilicals, protections, monitoring and control systems [77], [78], needs to be optimized: pressure tolerance, [79] and reliability [80] of the power electronics are the most critical concerns due to the prohibitive environmental conditions.

\section{Deep-sea Mining}

Apart from O\&G applications, the boundaries of subsea operations and processing are now being pushed forward by the emerging of deep-sea mining [14], e.g. the extraction of seafloor massive sulfides (SMS) such as zinc, copper, silver and gold, in water depths between 1 and $4 \mathrm{~km}$, at sites where the mineral concentration is much higher than in onshore mines. The first SMS deep-sea mining project, Solwara I, is supposed to start operation in 2018 offshore Papua New Guinea [58]. The mining of the selected site at 1600 mbsl will require heavy workclass Remotely-Operated Vehicles (ROVs). They will need to face the unprecedented technical challenges of excavation in hyperbaric conditions and ore transportation to the sea surface. Despite the similarity in the principle of operation, deep-sea mining may have higher power requirements than similar onshore mining applications. In particular, three different ROVs (Bulk and Auxiliary Miners and Collecting Machine), each with an installed power between 1.8 and $2.5 \mathrm{MW}$, are supposed to operate in this first project, in addition to the suction pump $(>6 \mathrm{MW})$. The power generation capability of the supporting vessel is $31 \mathrm{MW}$ for a nominal production rate of 1.8 million tons/year (dry equivalent) [58]. Since power consumptions and design considerations are strongly dependent on the depth of operation, subsea mining in deeper waters can be even more demanding [81], [82]. Moreover, a general trend in the ROV industry is to migrate from hybrid electric/hydraulic solutions to all-electric ones [83], since the use of hydraulics for power transmission can reduce the efficiency up to $50 \%$ [84], whereas the advantages of all-electric ROVs are: higher reliability, reduced size and weight, high efficiency and no leakage risks. Due to the absolute novelty and lack of any operational experience on any deep-sea mining projects, powering solutions based on renewable energies have not yet been considered, unlike the case of onshore mines, where sustainable power generation has been proposed [85], [86].

\section{Aquaculture Applications}

Although much less energy consuming compared to the previous applications, the aquaculture sector is one of the competitors for the use of the marine space and contributors to the offshore electric demand. In the aquaculture industry, there is a trend towards using more exposed coastal areas [87] and offshore locations [88] for fish farming, with the advantage of reducing key environmental effects, but with a possible increase 
in the local energy need.

The typical power consumption of fish farms is characterized by high variability, depending on the production cycles (e.g. hatchery/nursery, grow-out, harvesting or delivery phases), with the feeding phase accounting for up to $60 \%$ of the total energy consumption [89]. The maximum electric load is typically in the range $100-200 \mathrm{~kW}$ per installation, depending on size and location. Installed power can exceed three times the actual power demand, when locally supplied; whereas grid-connected solutions are now being implemented to mitigate the environmental impact of diesel generation [89].

\section{Marine Renewable Energy Resources}

Marine energy resources include both offshore wind and ocean renewable energy, where the latter category groups all possible green resources that stem from ocean waters, i.e. tidal energy, wave energy, ocean thermal energy conversion (OTEC) and salinity gradient. Offshore winds are steadier and more powerful than onshore ones, and their exploitation can minimize drawbacks such as scarcity of available land space and visual impact. On the other hand, the higher criticality and cost of Operation and Maintenance (O\&M) in offshore wind farms (Fig. 5), typically reduces their availability to between $90 \%$ and $95 \%$, whereas it is about $97 \%$ for onshore power plants [90]. Offshore wind turbines are following the technological trend of onshore wind, with a consistent increase in the average size and capacity of the installed wind turbines, which, in Europe, reached 5.9 MW in 2017 ( $+23 \%$ increase compared to the previous year) [91]. Some of the biggest challenges of offshore wind deployments compared to onshore ones lie in structural aspects, considered that wind turbine foundations represent a quarter to a third of the overall cost of an offshore turbine, for which installed strength, fatigue load, resistance to dynamic loadings, resistance to scour and corrosion are critical aspects [92]. From an electrical and control standpoint, power electronics covers $100 \%$ of the turbine installations since 2005 [93], and full scale power converters are increasing their share, especially for large turbines, although partially rated ones, used with doubly fed-induction generators, still dominate the market [94]. The largest offshore wind turbine is rated 9.5 MW [95] and, globally, the offshore wind capacity operational in 2017 exceeded $18.8 \mathrm{GW}$ [96].

Feasibility and high performance of floating wind turbines, recently tested in array configuration [97], will further impulse the sector. Therefore, the offshore wind installed capacity is expected to reach $66 \mathrm{GW}$ by 2030 [98].

Apart from wind, a significant amount of energy is present in ocean waters (Fig. 6). According to [99], the theoretical potential of tidal power (including tidal range and tidal currents) is $26,280 \mathrm{TWh} / \mathrm{year}$; the corresponding potential of wave energy is $32,000 \mathrm{TWh} /$ year and the theoretical potential associated to OTEC, (i.e. exploiting temperature differences above 20 degrees between surface and deep waters through thermal cycles), has been calculated in 44,000 TWh/year. Finally, salinity gradient (i.e. electricity production by osmotic processes exploiting the different concentration of salt in fresh and salt waters), could

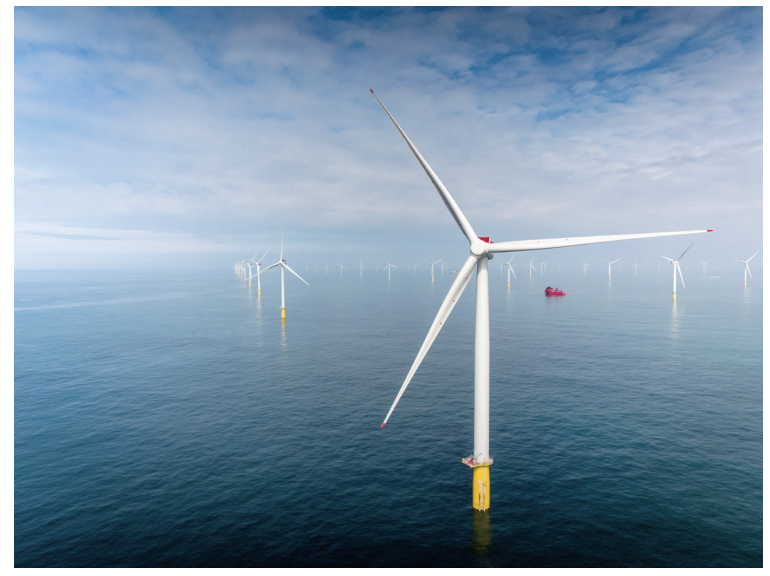

Fig. 5. Dudgeon offshore wind farm with $402 \mathrm{MW}$ generation capacity located in the North Sea, England (photo: courtesy of Statoil).

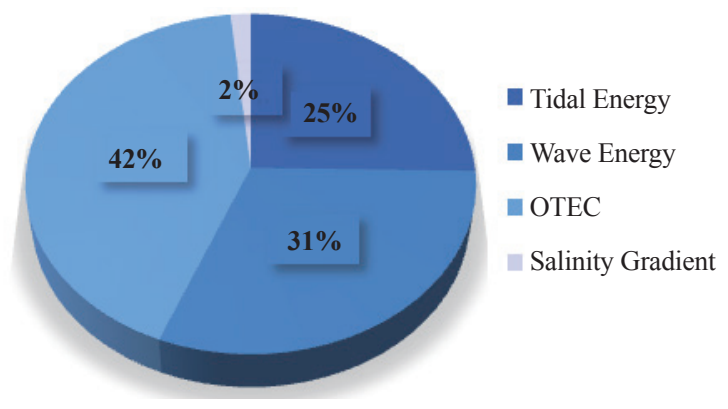

Fig. 6. Potential of ocean energy resources.

provide additional 1,650 TWh/year.

Despite the huge potential of ocean energy, the actual exploitable resource depends on the corresponding technological maturity, which is still low. Ocean thermal and salinity gradient technologies have so far been deployed only in few demonstration projects worldwide and are far from technological maturity. On the contrary, tidal energy is technologically established. Tidal barrage plants are in operation in grid connected mode both in Europe (La Rance, France, 240 MW) and Asia (Sihwa Barrage, Korea, $254 \mathrm{MW}$ ) [99] and tidal current harvesting has been successfully proved in several test sites [100], [101], exploiting the synergies with the wind turbines technology [99]. Wave energy was extensively researched in the last decades, but the high concept diversification [102] and need for tailored design and control solutions [103] have slowed-down the sector development, which is still at pre-commercial stage [104]. In total, in 2016, $0.5 \mathrm{GW}$ of commercial ocean energy generation capacity was in operation and $1.7 \mathrm{GW}$ under construction [105], $99 \%$ of which were tidal range. The estimated installed capacity of ocean energy by 2050 is up to $300 \mathrm{GW}$ from wave and tidal, plus $300 \mathrm{GW}$ from OTEC [102].

Other innovative renewable energy solutions have also been recently proposed to complement and diversify the offshore renewable energy portfolio. One example is constituted by floating photovoltaic plants such as those recently deployed offshore the Netherlands [106]. 


\section{OfFShORE ENERgy STORAGE}

In the last years, the deployment of offshore energy storage systems (ESS) gained momentum, representing a key enabling technology for the implementation of distributed marine energy systems, in particular to mitigate the intermittency and non-dispatchability of offshore renewables. Despite the potential advantages related to the deployment close to power generation sources (i.e. reduced costs for power transmission), limited environmental and visual impact and availability of vast spaces, offshore ESS presents additional challenges compared to onshore solutions. These are due to the harsh sea environment (with risk of corrosion, chemical deterioration etc.), need of high power and energy density, low-maintenance requirements, ballasting and mooring. Still, battery solutions have been often investigated for marine applications and were recently implemented in hybrid offshore wind farms. Currently, offshore battery deployment is considered a feasible solution [107] and, from the industrial standpoint, it is seen as an extension of battery use in the maritime applications [108]. The use of fuel cells is also being considered, due to high power density and good efficiency, modularity, good dynamic load-following characteristics, and reduced emissions [109].

Apart from chemical storage, using flywheels can be a viable option [110], due to their higher lifetime, allowing a number of charge/discharge cycles in the order of 25,000-50,000. Moreover, underwater compressed air energy storage (CAES), exploiting the advantage of high hydrostatic pressure on the seabed, has been recently investigated and tested at small scale by Hydrostor [111]. Similar properties are exploited by the Underwater Pumped Hydro Storage (UPHS), as in the concepts proposed and tested by Fraunhofer institute [112], MIT [113], and other institutions worldwide [114]. Although different energy storage technologies can be considered [11] depending on the power and energy requirements of the services to be provided (as further investigated in Section V), the largest installations such as underwater CAES and UPHS face additional challenges compared to the corresponding onshore versions. These relate to the potential unavailability of vessels suitable for the deployment of large devices at water depth of hundreds of meters [115].

\section{Distributed Energy Resources (DERs) to Supply OCEAN LOADS}

The characterization of offshore/subsea electric grids as distributed energy systems was explored only recently to: 1 ) verify the complementarity of different offshore energy sources; 2) investigate potential, challenges and optimum sizing of ESS for ocean applications; 3 ) prove the suitability of offshore renewables to supply local loads, without compromising stability and efficiency of the electric grids.

In particular, [116] explores the complementarity of wind and wave energy at three different European test-sites and shows a good matching between the power production of such marine renewables and the corresponding UK electricity consumption pattern. Ref. [117] presents a similar analysis for an Irish test case. A general review of possibilities for combined wind/wave installations is contained in [118].

ESS effect on the short-term stabilization of single offshore renewable sources has been analyzed and applied, in the case of wind installations, over time intervals of 15-60 minutes (i.e. for power smoothing, frequency regulation, capacity firming etc.) in [119] and [120], as well as on longer timescales (i.e. for energy management). Studies on ESS for wave energy applications over different time horizons also exist [121]-[123]. In some cases, the analysis is extended to multiple energy resources for both short-term (power smoothing over few seconds [124]) and long-term ([125]) applications. It is worth noting that the selected domain of application for the optimal energy storage sizing is quite often that of small islands [122], [126], whose power consumption and power system challenges are, however, similar to those of isolated $O \& G$ platforms.

Whereas previous investigations on marine renewable sources and energy storage deployments targeted general offshore loads, analyses related to the use of marine renewables to meet the power consumption of specific offshore applications and the impact on the corresponding local power systems have been only recently presented. Most of the contributions target wind integration into the electric distribution systems of O\&G platforms. In particular, [127] checks grid code compliance in terms of frequency and voltage stability under load start-up and lossof-load conditions. Ref [128] considers similar scenarios, in addition to the loss-of-generation case, analyzing the integration of a large wind farm in an $O \& G$ field and performs loss analysis. In [129], voltage and frequency stability are assessed for multiple test cases, and $\mathrm{NO}_{\mathrm{x}}$ and $\mathrm{CO}_{2}$ emissions reduction due to wind connection is quantified. The effect of short term wind variability, however, was only taken into account in [130] and [131]: [130] is a basic energy analysis, whereas [131] includes voltage and frequency stability studies under rapidly varying wind conditions, with the goal of assessing grid code compliance, according to the IEC-61892 standard.

Finally, possible stability risks due to electro-mechanical oscillations are addressed in [132] and load management is proposed as a mitigation measure.

The use of wind power to supply subsea equipment, i.e. water injection systems, was proposed by DNV GL and found technically and economically feasible by the joint industrial project WinWin [133]. Moreover, various techno-economic studies to quantify the advantages of supplying aquaculture installations with renewable energy exist. In particular, [134] and [135] evaluate the potential of multiple energy sources (wind, ocean, micro-hydro, solar, etc.) to cover the power need of realistic fishfarms. Plans for a pilot-project using wave power to supply fish farms were proposed by Albatern in [136], whereas the use of a small-scale OTEC system for seaweed production was tested in [137]. TABLE II surveys the main aspects of subsea/offshore DER systems and related grid services investigated in recent studies.

\section{Emerging Trends in Offshore and Subsea Grids}

The development of offshore and subsea electric grids, with high degree of flexibility and interconnection can be expected 
TABLE II

Survey of the Main Studies Investigating Aspects of Subsea/Offshore DER Systems and Related Grid Services

\begin{tabular}{|c|c|c|c|c|c|c|c|c|c|c|c|c|c|c|}
\hline & \multicolumn{5}{|c|}{ Major offshore loads } & \multicolumn{5}{|c|}{ Marine renewable generation } & \multicolumn{4}{|c|}{ Offshore storage } \\
\hline $\begin{array}{l}\text { Considered } \\
\text { services }\end{array}$ & $\begin{array}{l}\text { Generic } \\
\text { loads }\end{array}$ & $\begin{array}{l}\text { Oil and } \\
\text { Gas plat- } \\
\text { form }\end{array}$ & $\begin{array}{l}\text { Subsea } \\
\text { pro- } \\
\text { cessing }\end{array}$ & $\begin{array}{l}\text { Deep- } \\
\text { sea } \\
\text { mining }\end{array}$ & $\begin{array}{l}\text { Aquacul- } \\
\text { ture }\end{array}$ & $\begin{array}{l}\text { Wind } \\
\text { energy }\end{array}$ & $\begin{array}{l}\text { Wave } \\
\text { energy }\end{array}$ & $\begin{array}{l}\text { Tidal } \\
\text { energy }\end{array}$ & $\begin{array}{l}\text { Solar } \\
\text { energy }\end{array}$ & OTEC & $\begin{array}{l}\text { Generic } \\
\text { ESS }\end{array}$ & Batteries & $\begin{array}{l}\text { CAES/ } \\
\text { UPHS }\end{array}$ & $\begin{array}{l}\text { Fly- } \\
\text { wheels }\end{array}$ \\
\hline $\begin{array}{l}\text { Power } \\
\text { smoothing }\end{array}$ & $\begin{array}{l}{[121]} \\
{[123]}\end{array}$ & & & & & $\begin{array}{l}{[107][124]} \\
{[125]}\end{array}$ & $\begin{array}{l}{[121][123]} \\
{[124][125]}\end{array}$ & & & & $\begin{array}{l}{[121]} \\
{[125]}\end{array}$ & [107] & [123] & \\
\hline $\begin{array}{l}\text { Variability } \\
\text { reduction }\end{array}$ & [116] & & & & & {$[116][117]$} & {$[116][117]$} & & & & & & & \\
\hline $\begin{array}{l}\text { Loss reduc- } \\
\text { tion/ Efficien- } \\
\text { cy improve- } \\
\text { ment }\end{array}$ & & $\begin{array}{l}{[128]} \\
{[131]}\end{array}$ & [74] & [81] & $\begin{array}{l}{[89][134]} \\
{[137]}\end{array}$ & $\begin{array}{l}{[89][107]} \\
{[128][131]} \\
{[134]}\end{array}$ & [134] & & [134] & [137] & & [107] & & {$[110]$} \\
\hline $\begin{array}{l}\text { Voltage } \\
\text { stability }\end{array}$ & & $\begin{array}{l}{[64][65]} \\
{[127][128]} \\
{[130]}\end{array}$ & & & & $\begin{array}{l}{[64][127]} \\
{[128][130]}\end{array}$ & & & & & & & & \\
\hline $\begin{array}{l}\text { Frequency } \\
\text { stability }\end{array}$ & & $\begin{array}{l}{[64][65]} \\
{[127][128]} \\
{[130]}\end{array}$ & & & & $\begin{array}{l}{[64][127]} \\
{[128][130]}\end{array}$ & & & & & & & & \\
\hline $\begin{array}{l}\text { Power quality } \\
\text { evaluation } \\
\text { (flicker/har- } \\
\text { monic etc.) }\end{array}$ & & [69] & [74] & & & & & {$[100]$} & & & & & & \\
\hline $\begin{array}{l}\text { Energy man- } \\
\text { agement }\end{array}$ & {$[122]$} & & & & $\begin{array}{l}{[134][135]} \\
{[136]}\end{array}$ & $\begin{array}{l}{[122][126]} \\
{[134][135]}\end{array}$ & $\begin{array}{l}{[122][126]} \\
{[134][135]} \\
{[136]}\end{array}$ & [135] & $\begin{array}{l}{[134]} \\
{[135]}\end{array}$ & & $\begin{array}{l}{[120][122]} \\
{[126]}\end{array}$ & & & \\
\hline $\begin{array}{l}\text { Load man- } \\
\text { agement }\end{array}$ & & [132] & & & & [132] & & & & & & & & \\
\hline $\begin{array}{l}\mathrm{CO}_{2}-\mathrm{NOx} \\
\text { Emission } \\
\text { reduction }\end{array}$ & & $\begin{array}{l}{[64][130]} \\
{[131]}\end{array}$ & [133] & & & $\begin{array}{l}{[64][130]} \\
{[131][133]}\end{array}$ & & [101] & & & & & & \\
\hline
\end{tabular}

in the next years, and increased monitoring [138] and control [139] capabilities will underpin the digital transformation [140], [141] in the offshore sector. Among the emerging trends in the deployment of such systems, distributed energy storage integration is ongoing, which will help mitigating renewable energy intermittency and power quality issues in the local grids. This will extend the pervasive use of power electronics, used for renewable energy grid integration, electric drives for ocean loads and, potentially, power conditioning for power quality enhancement. Power electronics for ocean applications will require new solutions in terms of pressure [142] and fault tolerance [143], component miniaturization and physic of failure approach for reliability analyses [144]. Furthermore, the interconnection of otherwise-isolated offshore electric distribution systems to offshore HVDC and HVAC grids will push the innovation from component-level to system-level. Considering the increasing number of offshore HVDC deployments [145], Medium Voltage DC grids, already emerging in the maritime sector [146], could be extended to some offshore and subsea systems [147], [148].

\section{CONCLUSIONS}

The paper offers an up-to-date review of the main offshore and subsea applications. It shows the evolution of marine renewable sources and energy storage systems, outlining how their synergy can be the enabler of the ocean space energization and the adoption of smart grid models in the marine environment.

\section{REFERENCES}

[1] J. Joy, E. A. Jasmin, and V. R. John, “Challenges of smart grid." International Journal of Advanced Research in Electrical Electronics and Instrumentation Engineering, vol. 2, no. 3, pp. 976-981, 2013.

[2] A. G. Gonzalez-Rodriguez, "Review of offshore wind farm cost components," Energy for Sustainable Development, vol. 37, pp. 10$19,2017$.

[3] A. Colmenar-Santos, J. Perera-Perez, D. Borge-Diez, and C. dePalacio-Rodríguez, "Offshore wind energy: A review of the current status, challenges and future development in Spain," Renewable and Sustainable Energy Reviews, vol. 64, pp. 1-18, 2016.

[4] J. Rhodri and M. C. Ros, "Floating offshore wind: Market and technology review prepared for the scottish government," Carbon trust report, Jun. 2015.

[5] M. Melikoglu, "Current status and future of ocean energy sources: A global review," Ocean Engineering, vol. 148, pp. 563-573, 2018.

[6] A. Uihlein and D. Magagna, "Wave and tidal current energy - A review of the current state of research beyond technology," Renewable and Sustainable Energy Reviews, vol. 58, pp. 1070-1081, 2016.

[7] H. Titah-Benbouzid and M. Benbouzid, "An up-to-date technologies review and evaluation of wave energy converters," International Review of Electrical Engineering-Iree, vol. 10, no. 1, pp. 52-61, 
2015.

[8] C. Gerwick, in Construction of Marine and Offshore Structure, 2nd edition, 2002.

[9] Y. Bai and W. L. Jin, in Marine Structural Design, 2nd edition, 2015.

[10] T. C. Lommasson, "Optimization of Electrical Energy Production in Offshore Installations," Presentation Aug 25, 2015.

[11] Z. Zhou, M. Benbouzid, J. F. Charpentier, F. Scuiller, and T. Tang, "A review of energy storage technologies for marine current energy systems," Renewable and Sustainable Energy Reviews, vol. 18, pp. 390-400, 2013.

[12] D. O'Sullivan, D. Murray, J. Hayes, M. G. Egan and A. W. Lewis, "The benefits of device level short term energy storage in ocean wave energy converters," Energy Storage in the Emerging Era of Smart Grids, Rosario Carbone (Ed.).[Online]. Available: http:// www.intechopen.com/books/energy-storage-in-the-emerging-eraof-smart-grids/the-benefits-of-device-level-short-term-energy-storage-in-ocean-wave-energy-converters

[13] E. R. Jefferys, "What can wave energy learn from offshore oil and gas?" Philosophical Transactions R. Soc. A, vol. 370, no. 1959, pp. 439-450, 2012.

[14] P. Fairley, "Robot miners of the briny deep," in IEEE Spectrum, vol. 53, no. 1, pp. 44-47, Jan. 2016.

[15] Gina Krog (oil and gas platform).[Online].Available: https://www. offshore-technology.com/projects/dagny-field/.

[16] Aasta Hansteen (oil and gas platform).[Online].Available: https:// www.statoil.com/en/magazine/pioneers-aasta-hansteen.html.

[17] Johan Castberg (oil and gas platform).[Online].Available: https:// www.statoil.com/en/what-we-do/new-field-developments/johan-castberg.html.

[18] Johan Sverdup (oil and gas platform).[Online].Available: https:// www.statoil.com/en/what-we-do/johan-sverdrup.html.

[19] Martin Linge (oil and gas platform).[Online]. Available: http://factpages.npd.no/ReportServer?/FactPages/PageView/field\&rs:Command $=$ Render\&rc:Toolbar $=$ false $\& \mathrm{rc}:$ Parameters $=\mathrm{f} \& \mathrm{NpdId}=$ 21675447\&IpAddress=129.241.220.211\&CultureCode=en

[20] Goliat (oil and gas platform).[Online].Available: https://www.statoil.com/en/what-we-do/partner-operated-fields-in-norway/goliat. $\mathrm{html}$.

[21] Peregrino (oil and gas platform).[Online].Available: http://gcaptain. com/crazy-amounts-power-needed-statoils/.

[22] Statfjord A (oil and gas platform).[Online].Available: https://www. norskpetroleum.no/en/facts/field/statfjord/.

[23] Kvitebjorn (oil and gas platform).[Online].Available: https://sysla. no/offshore/feltdata/?navn=KVITEBJ\%C3\%98RN/facts/field/ kvitebjorn/.

[24] Snorre B (oil and gas platform).[Online].Available: http://www offshore-mag.com/articles/print/volume-60/issue-4/technology/ combined-cycle-plant-to-power-snorre-production-platforms.html.

[25] Brent (oil and gas platform).[Online].Available: https://www.offshore-technology.com/projects/brentfieldnorthseaun/.

[26] Bonga (oil and gas platform).[Online].Available: http://www. offshore-mag.com/articles/print/volume-62/issue-3/news/bongakizomba-set-benchmark-for-large-fpso-vessels.html.

[27] Heritage (oil and gas platform).[Online].Available: http://www.sbcountyplanning.org/energy/projects/exxon.asp.

[28] Harmony (oil and gas platform).[Online].Available: http://subseaiq. $\mathrm{com} /$ data/PrintProject.aspx?project_id=347.

[29] R. E. Olson, D. R. Olsen, J. D. Rullman, and F. G. Vasser, "Hondo field development and operations," Offshore Technology Conference, vol. 2, no. 5, pp. 227-228, 1983.

[30] Scarabeo 9 (oil and gas platform).[Online].Available: http://www. offshore-mag.com/articles/print/volume-62/issue-2/news/mauritania-drilling-campaign-indicates-emerging-deepwater-province.html

[31] Scarabeo 7 at Chinguetti (oil and gas platform).[Online].Available: http://www.saipem.com/SAIPEM_en_IT/scheda/Vessels/Scarabeo+7.page.

[32] Aban VIII (oil and gas platform).[Online].Available: http://www. abanoffshore.com/rigfleet/Aban\%20VII-TechSpec.pdf.

[33] Snohvit (subsea processing plant).[Online].Available:https://www statoil.com/en/what-we-do/norwegian-continental-shelf-platforms/ snohvit.html.

[34] Asgard (subsea processing plant).[Online].Available: https://www. statoil.com/en/what-we-do/norwegian-continental-shelf-platforms/ asgard.html

[35] Mikkel and Midgard (subsea processing plant).[Online].Available: https://www.statoil.com/en/what-we-do/norwegian-continental-shelf-platforms/mikkel.html

[36] Tyrihans (subsea processing plant).[Online]. Available:http://www. fmctechnologies.com/en/SubseaSystems/GlobalProjects/Europe/Norway/StatoilTyrihans.aspx?tab=\{DB36EABC-91BA-4AA6-9E7C-051B02D$\mathrm{DE} 0 \mathrm{~A} 2\}$

[37] Albacora- l'este field (subsea processing plant).[Online].Available:http://www.iingen.unam.mx/es-mx/BancoDeInformacion/ MemoriasdeEventos/Documents/RecursosEnergeticos Evento $2008 / 14 \% 20$ Petroleum $\% 20$ and $\% 20$ Natural $\% 20$ Gas $\% 20$ in $\% 20$ Brazil_.pdf

[38] Troll C (subsea processing plant).[Online].Available:https://www. statoil.com/en/what-we-do/norwegian-continental-shelf-platforms/ troll.html.

[39] Tordis (subsea processing plant).[Online].Available: https://www. statoil.com/en/what-we-do/norwegian-continental-shelf-platforms/ tordis.html.

[40] Parque Das Conchas (subsea processing plant).[Online].Available: http://www.fmctechnologies.com/en/SubseaSystems/GlobalProjects/South\%20America/Brazil/ShellParquedasConchas.aspx\#

[41] Perdido (subsea processing plant).[Online].Available: https://www. reuters.com/article/shell-gom-stones/update-4-shell-to-developworlds-deepest-offshore-oil-platform-idUSL2N0DP1I420130508.

[42] Pazflor (subsea processing plant).[Online].Available: http://www. subseaiq.com/data/Project.aspx?project_id=326\&AspxAutoDetectCookieSupport $=1$.

[43] Marlim (subsea processing plant).[Online].Available: https://brage. bibsys.no/xmlui/bitstream/handle/11250/266220/626516_FULLTEXT01.pdf? sequence=1\&isAllowed=y.

[44] Mutineer (subsea processing plant).[Online].Available: https://www nopsema.gov.au/assets/epdocuments/MUEX-2000-PLN-0004-Summary-EP-Rev1.pdf.

[45] Brenda\&Nicol fields (subsea processing plant).[Online].Available: http://www.premier-oil.com/premieroil/dlibrary/panda/the-balmoral-oil-fields.pdf.

[46] Vincent (subsea processing plant).[Online].Available: https://www. offshore-technology.com/projects/vincent-field/.

[47] Golfinho Field (subsea processing plant).[Online].Available: https:// www.offshore-technology.com/projects/golfinhofieldespirit/.

[48] Parque Das Conchas (ph 1) (subsea processing plant).[Online]. Available: http://www.fmctechnologies.com/en/SubseaSystems/ GlobalProjects/South\%20America/Brazil/ShellParquedasConchas. aspx\#.

[49] Parque Das Conchas (ph 2) (subsea processing plant).[Online]. Available: http://www.fmctechnologies.com/en/SubseaSystems/ GlobalProjects/South\%20America/Brazil/ShellParquedasConchas. aspx\#.

[50] Jubarte field (subsea processing plant).[Online].Available: https:// www.offshore-technology.com/projects/jubarte-field.

[51] Barracuda (subsea processing plant).[Online].Available: http://www. offshore-technology.com/projects/barracuda-caratinga-fields-brazil/.

[52] Montanazo \& Lubina (subsea processing plant).[Online].Available: http://www.subseaiq.com/data/Project.aspx?project_id=1118.

[53] Jack \& St Malo (subsea processing plant).[Online].Available: https://www.chevron.com/-/media/chevron/projects/documents/ JSM-Making-It-Happen-Video-Transcript.pdf.

[54] Rosa/Girasol (subsea processing plant).[Online].Available: http:// www.subseaiq.com/data/Project.aspx?project_id $=325$.

[55] Draugen (subsea processing plant).[Online].Available: https://www. fircroft.com/blogs/engineering-feat-of-the-month-draugen-platform-63012712241.

[56] Julia (subsea processing plant).[Online].Available: http://www.offshore-technology.com/projects/julia-field-gulf-mexico/.

[57] Parque das baleias (subsea processing plant).[Online].Available: http://www.investidorpetrobras.com.br/en/press-releases/start-platform-p-58-parque-das-baleias. 
[58] Papua New Guinea (deep-sea mining).[Online].Nautilus Minerals website. Available: http://www.nautilusminerals.com/irm/content/ png.aspx?RID $=258$.

[59] Z. A. Nawab, "Red Sea mining: A new era," Deep Sea Research Part A. Oceanographic Research Papers, vol. 31, no. 6-8, pp. 813$822,1984$.

[60] R. B. Pedersen, "Discovery of a black smoker vent field and vent fauna at the Arctic Mid-Ocean Ridge," Nature Communications, vol. 1 , no. 8, p. 126, 2010.

[61] Rataren (fish farm).[Online].Available: http://www.tandfonline. com/doi/full/10.1080/08927014.2015.1012713?scroll=top\&needAccess $=$ true \&.

[62] Rigzone, "Offshore Rig Fleet by Region," Jan. 2018.[Online].Available: http://images.rigzone.com/data/rig report.asp?rpt=reg.

[63] Oilscams.org, "The Differences Between Offshore And Onshore Oil Drilling," Infographics, 2014.[Online].Available: http://www. oilscams.org/offshore-vs-onshore-oil-drilling.

[64] W. He, K. Uhlen, M. Hadiya, Z. Chen, G. Shi, and E. del Rio, "Case study of integrating an offshore wind farm with off-shore oil and gas platforms and with an onshore electrical grid," Journal of Renewable Energy, p. 10, 2013.

[65] P. Jakobsen, G. Peck, and E. Snow, "Electrical power system challenges during the expansion of offshore oil \& gas facilities," in Proc. of the 2012 Petroleum and Chemical Industry Conf. Europe (PCIC EUROPE), Prague, 2012, pp. 1-9.

[66] Offshore Energy Today, "Caterpillar Gensets for Russia's Largest Offshore Platform," Mar. 7, 2013.[Online].Available: https://www. offshoreenergytoday.com/caterpillar-gensets-for-russias-largest-offshore-platform/

[67] Himoinsa, "Himoinsa generator sets used in construction of new oil platforms in Mexico," [Online].Available: http://www.himoinsa.com/ eng/news/60/news/generator-sets-oil-platforms-in-mexico.html.

[68] K. Schipman, F. Delincé, "The importance of good power quality," ABB Review, 2010.

[69] I. C. Evans and R. Al-Khaimah, "The importance of acceptable electrical power quality to the drilling industry worldwide," in Proc. of SPE/IADC Middle East Drilling Technology Conference and Exhibition, Dubai, 2013, pp. 1-22.

[70] E. Eriksson, M. Jeroense, M. Larsson-Hoffstein, C. Sonesson, K-A. Farnes, R. O. Råd, and K. A. Stenevik, "HVAC power transmission to the Gjøa platform," in 8th Int. Conf. on Insulated Power Cables, Versailles, France, Jun. 2011.

[71] N. G. van Luijk, "Delivering energy through the world longest submarine HV AC cable," in 2015 IEEE Power \& Energy Society General Meeting, Denver, CO, 2015, p. 1.

[72] H. Myklebust, K. Eriksson, B. Westman and G. Persson, "Valhall power from shore after five years of operation," in 2017 Petroleum and Chemical Industry Conference Europe (PCIC Europe), Vienna, 2017, pp. 1-4.

[73] H. Devold and T-E. Moen, "Electrification, energy efficiency \& power from shore," ABB present. 31 May 12.[Online].Available: www04.abb.com/global/dkabb/dkabb504.nsf/0/6c0627884bb4ae62c1257a1a0045b877/\$file/Electrification+Energy+Efficiency+and+Power.pdf.

[74] M. Yamamoto, C. F. M. Almeida, B. A. Angelico, D. Colon, and M. B. C. Salles, "Integrated subsea production system: An overview on energy distribution and remote control," in Petroleum \& Chemical Industry Conf. Brasil 2014, Rio, pp.173-181, 2014.

[75] Statoil, "The first subsea gas compression plant in the world on line," Press release. 2015.

[76] T. Dabade et al., "2017 Worldwide survey of subsea processing and active heating systems," Offshore Magazine, Mar. 17.

[77] T. Hazel, H. Baerd, J. J. Bremnes and J. Legeay, "Subsea high-voltage power distribution," in 2011 Record of Conf. Papers Industry Applic. Soc. 58th Annual IEEE Petroleum \& Chemical Industry Conference (PCIC), Toronto, ON 2011, pp. 1-9.

[78] K. Rajashekara and H. Krishnamoorthy, "Power electronics for subsea systems: Challenges and opportunities," in 2017 IEEE 12th Int. Conf. on Power Electronics and Drive Systems (PEDS 2017), Honolulu, Hawaii, USA, Dec. 12-15, 2017.

[79] A. Petterteig, R. Pittini, M. Hernes, and O. Holt, "Pressure tolerant power IGBTs for subsea applications," in Power Electronics and Applications, 2009. EPE'09. 13 th European Conference on, IEEE, Sep. 2009, pp. 1-10.

[80] N. Vedachalam et al., "Review of maturing multi-megawatt power electronic converter technologies and reliability modeling in the light of subsea applications," Applied Ocean Research, vol. 46, pp. 28-39, 2014.

[81] R. Fard and E. Tedeschi, "Investigation of AC\&DC power distributions to seafloor mining equipment," in Oceans, 2017, pp.1-7.

[82] M. Ludvigsen et al., "ROV based drilling for deep sea mining exploration," in Oceans 2017, Aberdeen, UK, 2017, pp. 1-6.

[83] K. Siem, "Subsea 7 Annual report and consolidated financial statements 2016-chairman's statement," 2017, p. 2.

[84] R. Enzmann, "The Nexxus ROV: Revolutionizing operational efficiency," ROV planet, Is. 7, Q2, 2016.

[85] R. G. Votteler and A. C. Brent, "A mining perspective on the potential of renewable electricity sources for operations in South Africa: Part I - The research approach and internal evaluation process," in $J$. S. Afr. Inst. Min. Metall. [online]. vol. 117, no. 3, pp. 285-297, 2017.

[86] Sunshift, "Renewable energy in the Australian mining sector," White paper, Rev. 22017.

[87] H. V. Bjelland et al., "Exposed aquaculture in Norway," in Oceans 2015, MTS/IEEE, Washington, DC, 2015, pp. 1-10.

[88] A. Hoyle, "World's first offshore fish farm on its way to Norway," Fish farming expert Website, Jun. 06, 2017. [Online]. Available: https://www.fishfarmingexpert.com/news/worlds-first-offshore-fishfarm-on-its-way-to-norway/.

[89] A. Aspen Justad, "Wind turbines for the power supply for offshore fish farms a case study for the norwegian west coast" M.S. Thesis, University di Agder, 2017.

[90] G. L. Garrad Hassan, "A guide to UK offshore wind operations and maintenance," Scottish Enterprise and the Crown Estate, 2013.

[91] The European offshore wind industry. Key trends and statistics 2018, Feb. 2018.

[92] J. Lawson, "What are the challenges and innovations in offshore wind design and development?" Renewable Energy World, Aug. 22, 2011.

[93] F. Blaabjerg, M. Liserre and K. Ma, "Power electronics converters for wind turbine systems," IEEE Transactions on Industry Applications, vol. 48, no. 2, pp. 708-719, Mar.-Apr., 2012.

[94] J. Serrano-González and R. Lacal-Arantegui, "Technological evolution of onshore wind turbine," Wind Energy, vol. 19, no. 12, pp. 2171-2187, 2016.

[95] MHIVestas Offshore Wind. (2017, June). The world's most powerful available wind turbine gets major power boost.[Online]. Available: http://www.mhivestasoffshore.com/worlds-most-powerfulavailable-wind-turbine-gets-major-power-boost/.

[96] Global Wind Energy Council. (2018, February). Global wind statistics 2017. [Online]. Available: http://gwec.net/wp-content/uploads/ vip/GWEC_PRstats2017_EN-003_FINAL.pdf .

[97] Statoil. (2017, October). World's first floating wind farm has started production. [Online]. Available: https://www.statoil.com/en/news/ worlds-first-floating-wind-farm-started-production.html.

[98] WindEurope, "The European offshore wind industry".

[99] L. A. S. Estefen, J. Huckerby, W. Musial, T. Pontes, and J. Torres-Martinez, "Ocean energy," in IPCC Special Report on Renewable Energy Sources and Climate Change Mitigation Cambridge University Press, Cambridge, United Kingdom and New York, NY, USA, 2011.

[100] J. Macenri, M. Reed, and T. Thiringer, "Power quality performance of the tidal energy converter, SeaGen," in Proc. of the ASME 2011 30th Int. Conf. on Ocean, Offshore and Arctic Engineering, vol. 5, pp. 529-536, 2011.

[101] J. Simpson, "Grid-connected in-stream tidal turbine deployed in Canada,"in Engineering 360,IEEE GlobalSpec, Dec. 8, 2016.

[102] J. Huckerby, H. Jeffrey, A. de Andres, and L. Finlay. (2016). An International Vision for Ocean Energy. Version III. the Ocean Energy Systems Technology Collaboration Programme. [Online]. Available: www.ocean-energy-systems.org

[103] L. Wang, J. Isberg, E. Tedeschi, "Review of control strategies for wave energy conversion systems and their validation: the wave-to- 
wire approach," Renewable and Sustainable Energy Reviews, vol. 81, part 1, 2018, pp. 366-379.

[104] O. Edenhofer et al., "Technical summary," in IPCC Special Report On Renewable Energy Sources And Climate Change Mitigation, Cambridge University Press, Cambridge, United Kingdom and New York, NY, USA., 2011.

[105] World Energy Council, "World Energy Resources- Marine Energy 2016," Oct. 2016.

[106] E. Bellini, "Netherlands' first floating PV plant is under construction," PV magazine, Sept. 13, 2017. [Online]. Available: https:// www.pv-magazine.com/2017/09/13/netherlands-first-floating-pvplant-is-under-construction/.

[107] Statoil, "Statoil launches Batwind: Battery storage for offshore wind," Mar. 21, 2016. [Online]. Available: www.statoil.com/ content/dam/statoil/documents/newsroom-additional-documents/ news-attachments/batwind-presentation.pdf.

[108] Plan B Energy Storage Website. [Online]. Available: http://www. pbes.com/.

[109] O. Z. Sharaf and M. F. Orhan, "An overview of fuel cell technology: Fundamentals and applications," Renewable and Sustainable Energy Reviews, vol. 32, no. 5, pp. 810-853, 2014.

[110] T. Dragicevic, M. Speiermann, and J. Høffner, "Offshore application of the flywheel energy storage," Final report, Feb. 2016.

[111] K. Tweed, "Toronto hydro pilots world's first offshore compressed-air energy storage project," GreenTech Media, Nov. 25, 2015. [Online]. Available: https://www.greentechmedia.com/ articles/read/toronto-hydro-pilots-worlds-first-offshore-compressed-air-energy-storage\#gs.Sbb9vCI.

[112] J. Deign, "Fraunhofer tests a new underwater energy storage concept," GreenTech Media, Aug. 29, 2016. [Online]. Available: https:// www.greentechmedia.com/articles/read/fraunhofer-races-hydrostor-for-underwater-storage.

[113] A. H. Slocum, G. E. Fennell, G. Dundar et al., "Ocean renewable energy storage (ORES) system: Analysis of an undersea energy storage concept," Proceedings of the IEEE, vol.101, no. 4, pp.906924, 2013.

[114] D. Buhagiar, T. Sant, C. Micallef, and R. N. Farrugia, "Improving the energy yield from an open loop hydraulic offshore turbine through deep sea water extraction and alternative control schemes," Energy, vol. 84, pp. 344-356, 2015.

[115] J. Deign, "The promise of seabed storage," Energy Storage report, Oct. 16, 2013.

[116] L. Cradden, H. Mouslim, O. Duperray, and D Ingram, "Joint exploitation of wave and offshore wind power," in Proceedings of the 9th European Wave and Tidal Energy Conference, Southampton, UK, Sep. 2011, pp. 1-10.

[117] F. Fusco, G. Nolan, and J. V. Ringwood, "Variability reduction through optimal combination of wind/wave resources - An Irish case study," Energy, vol. 35, no. 1, pp. 314-325, 2010.

[118] C. Pérez-Collazo, D. Greaves, and G. Iglesias, "A review of combined wave and offshore wind energy," Renewable and Sustainable Energy Reviews, vol. 42, pp. 141-153, 2015.

[119] GE Renewable Energy Website, "Shifting the winds in your favor with energy storage," [Online]. Available: https://www.gerenewableenergy.com/wind-energy/technology/integrated-energy-storage-for-wind-turbines.

[120] O. C. Spro, O. Mo, K. Merz, and J. O. Tande, "Influence of technical limitations and operation on sizing of an offshore energy storage connected to an offshore wind farm," Energy Procedia, vol. 80, pp. 284-293, 2015.

[121] M. Lafoz, M. Blanco, L. Beloqui, G. Navarro, and P. Moreno-Torres, "Dimensioning methodology for energy storage devices and wave energy converters supplying isolated loads," IET Renew. Power Generation, vol. 10, no. 10, pp. 1468-1476, 2016.

[122] E. Tedeschi, J. Sjolte, M. Molinas et al., "Stochastic rating of storage systems in isolated networks with increasing wave energy penetration," Energies, vol. 6 no. 5, pp. 2481-2500, 2013.

[123] S. Jafarishiadeh, M. Farasat, and A. M. Bozorgi, "Modeling, analysis and design of an undersea storage system," in 2016 IEEE Energy Conversion Congress and Exposition (ECCE), Milwaukee, WI, 2016, pp. 1-6.
[124] X. Zhao, Z. Yan, and X. P. Zhang, "A wind-wave farm system with self-energy storage and smoothed power output," IEEE Access, vol. 4, pp. 8634-8642, 2016.

[125] E. Tedeschi, E. Robles, M. Santos, O. Duperray, and F. Salcedo, "Effect of energy storage on a combined wind and wave energy farm," in 2012 IEEE Energy Conversion Congress and Exposition (ECCE), Raleigh, NC, 2012, pp. 2798-2804.

[126] H. Marañon-Ledesma and E. Tedeschi, "Energy storage sizing by stochastic optimization for a combined wind-wave-diesel supplied system," in 2015 International Conference on Renewable Energy Research \& Applications (ICRERA), Palermo, pp.426-31, 2015.

[127] A. A. Rygg, T. Undeland, and K. Sharifabadi, "Voltage and frequency control in offshore wind turbines connected to isolated oil platform power systems," Energy Procedia, vol. 24, no. 24, pp. 229236, 2012.

[128] H. Svendsen et al., "Integration of offshore wind farm with multiple oil and gas platforms," in IEEE PowerTech, 2011 IEEE Trondheim IEEE, 2011, pp.1-3

[129] W. He, K. Uhlen, M. Hadiya, and Z. Chen, "Case study of integrating an offshore wind farm with offshore oil and gas platforms and with an onshore electrical grid," Journal of Renewable Energy, pp.1-10, 2013.

[130] W. He et al., "The potential of integrating wind power with offshore oil and gas platforms," Wind Engineering, vol. 34, no. 2, pp.125137, 2010.

[131] M. Korpas et al., "A case-study on offshore wind power supply to oil and gas rigs," Energy Procedia, no. 24, pp. 18-26, 2012.

[132] S. Sanchez et al., "Smart load management of water injection systems in offshore oil and gas platforms integrating wind power," IET Renewable Power Generation, vol. 11, no. 9, pp. 1153-1162, 2017.

[133] L. Asdal Danielsen, "Wind powered oil recovery concept moves closer to implementation," DNV GL press release, Apr. 19, 2017. [Online]. Available: https://www.dnvgl.com/news/wind-powered-oil-recovery-concept-moves-closer-to-implementation-90002.

[134] D. Toner, Mo Mathies, "The Potential for renewable energy usage in aquaculture," Report, Dec. 2002.

[135] Aquatera Ltd/SARF, "Renewable power generation on aquaculture sites," Report, Nov. 2013.

[136] Albatern and AquaBioTech, "Aquaculture \& wave energy combination," Project final report, 2016.

[137] K. Ouchi, M. Kurahashi, M. Shibuya, S. Tabeteta, and K. Iseki, "The real sea experiment of seaweed growing with DOW," in 2016 Techno-Ocean (Techno-Ocean), Kobe, 2016, pp. 235-238.

[138] G. Birrell, "The connected upstreaam," in the Rosneft Upstream Technologies Conference, Oct. 3, 2017.

[139] Y. Zhang, W. Tang, and J. Du, "Development of subsea production system and its control system," in 2017 4th International Conference on Information, Cybernetics and Computational Social Systems (ICCSS), Dalian, 2017, pp. 117-122.

[140] D. Paganie, "Assessing the digital transformation" Offshore Magazine, Jan. 10, 2017.[Online]. Available: http://www.offshore-mag. com/articles/print/volume-77/issue-10/department/comment/assessing-the-digital-transformation.html.

[141] International Energy Agency, "Digitalization and energy," Report, Nov. 5, 2017.

[142] R. Pittini, M. Hernes and Petterteig A, "Pressure-tolerant power electronics for deep\&ultradeep water," Oil\&Gas Facilities, no. 1, pp.47-52, 2014.

[143] N. Vedachalam, A. Umapathy, and G. A. Ramadass, "Fault-tolerant design approach for reliable offshore multi-megawatt variable frequency converters," Journal of Ocean Engineering and Science, vol. 1, no. 3, pp. 226-237, 2016.

[144] H. Wang et al., "Transitioning to physics-of-failure as a reliability driver in power electronics," IEEE Journal of Emerging and Selected Topics in Power Electronics, vol. 2, no. 1, pp. 97-114, Mar. 2014.

[145] A. Elahidoost and E. Tedeschi, "Expansion of offshore HVDC grids: An overview of contributions, status, challenges and perspectives," in 58th International Conference on Power \& Electrical Engineering of Riga Technical University (RTUCON) , Riga, 2017, p.7.

[146] U. Javaid, F. D. Freijedo, D. Dujic, and W. van der Merwe, "Dynamic 
assessment of source-load interactions in marine MVDC distribution," IEEE Transactions on Industrial Electronics, vol. 64, no. 6, pp. 4372-4381, Jun. 2017.

[147] B. M. Grainger et al., "Analysis of an offshore medium voltage DC microgrid environment - Part I: Power sharing controller design," in 2014 IEEE PES T\&D Conference and Exposition, Chicago, IL, USA, 2014, pp. 1-5.

[148] G. Bathurst, G. Hwang, and L. Tejwani, "MVDC: The new technology for distribution networks," in 11th IET International Conference on AC and DC Power Transmission, Birmingham, 2015, pp. $1-5$.

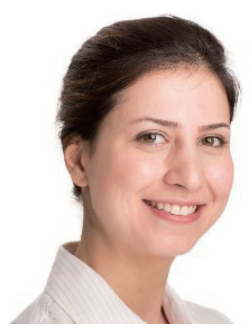

Razieh Nejati Fard received her B.Sc. degree in electrical engineering from the University of Tehran, Iran in 2010. She received the M.Sc. degree in electrical power engineering from the Norwegian University of Science and Technology in June 2013, working on Modular Multilevel Converters (MMC) and their controlling strategies, especially Model Predictive Control (MPC). She is currently a Ph.D. candidate working on the power system design for deep-sea mining applications. She is research assistant for the courses "Marine and Offshore Power Systems" and "Power System Analysis". Her research interests include power electronic converters, electrical drive systems and control strategies, in addition to the challenges deriving from their implementation in the subsea and offshore environments.

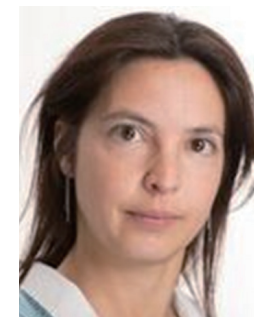

Elisabetta Tedeschi received the M.Sc. degree in electrical engineering and the Ph.D. degree in industrial engineering from the University of Padova, Italy, in 2005 and 2009, respectively.

From 2009 to 2011, she was a post doc researcher at the Norwegian University of Science and Technology (NTNU), working on the design and control of energy conversion systems for the grid integration of offshore renewable energies.

Having received a Marie Curie Fellowship, she was a Researcher at Tecnalia, Spain, from 2011 to 2013, where she worked as a principal investigator in the FP7-Sea2grid Project, related to the storage needs for the grid integration of wave energy converters.

From 2013 to 2014, she was Research Scientist at SINTEF Energy and Adjunct Associate Professor at NTNU. In 2014, she became Full Professor in offshore grid at NTNU.

She has a core competence in the design and control of energy conversion and transmission systems, with focus on offshore energy, and power-quality issues. She has led and/or contributed to more than 15 national and international scientific projects and she is the author or co-author of 1 book chapter and more than 15 journals and 40 conference papers in the field of marine energy and energy conversion systems. 